London's Olympic Ambassadors: A legacy for public policy implementation?

Margaret Harris

An article accepted for publication in the Policy Section of Voluntary Sector Review, 3, 3, November 2012.

Contact details for author:

Margaret Harris Ph.D.

Email: m.e.harris@aston.ac.uk

Mobile: 07860907779

Margaret Harris is Emeritus Professor of Voluntary Sector Organisation, Aston University, Birmingham; Visiting Professor at Birkbeck, University of London; and Academic Adviser to IVAR (Institute for Voluntary Action Research)

Word count: 3,554 including title, keywords, endnotes and references 


\title{
London's Olympic Ambassadors: A legacy for public policy implementation?
}

Key Words: London 2012; Olympic Games; Volunteers; Volunteer management; Team London

\begin{abstract}
As a contribution to current discussions about securing a legacy from the 2012 Olympic and Paralympic Games, this article considers whether there are lessons for public policy implementation around volunteer involvement. Drawing on the case of the Team London Ambassadors Programme which encompassed 8,000 volunteers during the Games period, the article considers the scope for an expanded role for UK public sector organisations in the recruitment, training and management of volunteers in the future.
\end{abstract}

\section{Introduction}

A noted feature of the London Olympics was the involvement of volunteers. The commitment to put 'inclusion' and sports volunteering at the heart of the Games was one of the factors which helped to secure the London bid to host the 2012 events (Lee, 2006). The widespread praise for the way in which the Games were organised was in large part attributable to the purple-shirted volunteer 'Games Makers' whose involvement and enthusiasm in events was evident to spectators around the world and publicly acknowledged in the closing Olympics ceremony. As post-Games debates about ensuring 'a legacy' continue, those who study the voluntary sector and volunteering should perhaps be pondering what lessons can be drawn from the Games experience for public policy implementation. Are we left with new models for involving volunteers in the delivery of public services?

The Games Maker project was organised by LOCOG (London Organising Committee of the Olympic and Paralympic Games) , the private company set up to prepare and stage the Games, with financing from sponsorship, ticket sales, broadcasting rights and sales of merchandise. Some of the recruitment and training of the Games Makers was done by McDonalds, the fast food chain and one of the 'Presenting Partners' for the Games. Uniforms and equipment provided for the volunteers carried the logos of other corporate LOCOG partners including Adidas and Coca Cola.

So the Games Maker project seems to provide an example of how private enterprise and for-profit corporations can contribute to the effective deployment of volunteers. It also suggests that voluntary sector organisations do not have a monopoly on motivating volunteers. The more than 200,000 people who applied to be Games Makers and the 70,000 who were selected were not, apparently, discouraged by the heavy business sector involvement. This supports findings in volunteering studies which suggest that a prime motivator for volunteers is the cause to be served; that auspices (the type of organisation recruiting and managing the volunteers) is less important for volunteers than their feeling that they have made a contribution to something they believe to be worthwhile (Clark et al, 2012; Clary et al, 1992). 
Yet since hosting of the Olympics and Paralympics is a once-in-a-lifetime experience for most countries and most potential volunteers, we should perhaps be cautious about drawing broad public policy lessons from the evident success of the Games Maker programme. As the literature on 'event' volunteering indicates (eg Farrell et al, 1998; Nichols and Ojala, 2009; Shaw, 2009), there were a number of special features of the Games Maker volunteering which may not apply more widely. It is one thing to commit oneself to a time-limited volunteering episode for an unusual and glamorous international event, quite another to get drawn into a commitment to help implement mainstream public policy goals by, for example, assisting in a local sports club, providing care services, or building 'Big Society' in one's local neighbourhood (Alcock, 2010; Mayo et al, 2012; Nichols et al, 2005).

\section{Team London Ambassadors}

However, there was another, less well publicised, volunteering programme developed to support the London Games which does suggest the possibility of more enduring lessons for public policy, in that it relied less on the glamour of a major international sporting event to attract volunteers and more on a general appeal to civic responsibility (South and Kinsella, 2001; Strickland, 2010). Moreover it was driven by a local government organisation rather than a time-limited and goallimited business sector organisation. More modest in scale than Games Makers, the 'Team London Ambassadors' programme (1) may nevertheless emerge as an important legacy for UK public policy implementation.

Launched by the Mayor of London in July 2010, the Team London Ambassadors Programme (hereafter 'TLAP') was intended to provide 'dedicated, enthusiastic and knowledgeable volunteers' based around London during the Games period at 43 visitor locations including tourist sites and travel hubs (Office of the Mayor of London, 2012, p5). The call for volunteers appealed to people who wanted to make London a welcoming place for visitors during a busy summer: "We're looking for volunteers to be the face of London; people who are passionate about the capital and want to tell millions of people about the hidden treasures that makes London one of the best capital cities in the world" (Team London Ambassadors website, undated).

From the start, then, it was clear that the Ambassadors programme was being sponsored by the Mayor of London and implemented by the staff of the Greater London Authority (GLA); primarily staff of 'Team London', the GLA's unit to promote volunteering. As the programme developed in the period preceding the Games, professional trainers and consultants were brought in to help train the Ambassadors and their managers (who were also volunteers). 'Team London' staff of the GLA remained 'in the driving seat' as regards the nature of the volunteers' roles and how they should be prepared but some preparatory tasks were delegated to outside experts (2).

Selected volunteer Ambassadors (8,000 chosen from the 22,000 who applied) were required to commit themselves to five-hour shifts on six consecutive days during the Games period. Three full days of compulsory training were provided; the third and final module taking place at the location where Ambassadors would be working, and delivered by those volunteers who would be managing 
them. The training of the Ambassadors combined transfer of information with an emphasis on the volunteers enjoying themselves.

Volunteers were required to sign a one page agreement which set out the expectations on them as well as what they could expect from the 'Team London Ambassadors Programme' (Office of the Mayor of London, 2012). A unisex uniform in Olympic colours of pink and purple (but different from the uniform supplied to Games Makers in several respects) was provided and sent to volunteers' homes prior to the Games. Ambassadors were required to wear their uniform while on duty and when travelling to and from work locations. Travel expenses within the London area were reimbursed and $£ 5$ provided per day for refreshments.

For those wishing to draw lessons for public policy implementation in the future, there are some noteworthy features of the TLAP. First, it appeared to be informed, directly or indirectly, by some of the key research and guidance on good practice in volunteer management (as set out for example by Hager and Brudney, 2004). Incidental expenses were reimbursed (at least for those living within London and with small appetites). Appropriate training, preparation and insurance were provided and CRB checks conducted. Throughout the training and working periods there was an emphasis on having fun and incentives to appeal to a variety of tastes were offered (including free or discounted tickets for sport and cultural events, but not for the Games themselves). During working periods, management was of a 'light touch' kind, reflecting a wish to ensure that volunteers had a good time and did not feel oppressed by rules. At the same time, the physical safety and wellbeing of volunteers was ensured through buddying, mentoring and on-site managers.

Second, and despite the relaxed attitude to managing volunteers on the ground, there were aspects of the programme which were clearly more rooted in the culture of the public sector and large, formal third sector organisations than in the informal culture of volunteer-involving voluntary and community organisations. Uniforms (themselves relatively unusual for volunteers recruited by charities and other third sector organisations in the UK) bore logos not of corporate sponsors (as did those of Games Makers) but of the 'Mayor of London' and of the Greater London Authority's (GLA's) broader and on-going volunteer-promoting project called 'Team London' (Team London website, undated). Volunteers were asked not to customise their uniforms in any way, to be smart and to conform with rules about shoe colour and type. (Members of the public could have been forgiven for assuming that the Ambassadors they met were local government or other public sector employees, albeit exceptionally friendly ones.) Again in keeping with public sector norms, great attention was paid to ensuring diversity (of ethnicity, country of origin, age and ability) within the volunteer force overall and also within working teams.

A third noteworthy feature of TLAP, was some apparently contradictory and ambiguous features. For example, the programme combined high degrees of both informality and formality. On the one hand there was little attempt to ensure the consistent quality of information offered to the public and Ambassadors on the ground had a quite a free hand to decide how they approached members of the public and responded to their needs. (Indeed, during training the volunteers were encouraged to share with the public their personal views about pubs, shops, restaurants, transport routes and London sights.) Yet on the other hand, volunteers were required to complete three full days of training and were required to work according to pre-set timetables on six consecutive days. Volunteers were also, as mentioned above, required to conform to strict rules about uniform. 
Again, despite attempts to ensure that volunteers' contributions were recognised in a variety of ways, and in accordance with accepted good practice for volunteer management, the vexed question of how to manage situations in which volunteers and paid staff work side by side was apparently not recognised as potentially problematic (Liao-Troth, 2001; Paine et al, 2010). 'Team London Ambassadors' on shifts at travel hubs found that they were working side by side with people called 'Team London Travel Champions' who were dressed in almost identical uniforms to their own, thus giving the impression to the public that there was no distinction between the two roles. Yet in fact the Travel Champions were mostly paid employees of Transport for London ( $\mathrm{TL} L$ ) who had been seconded from desk jobs during the Games Period to provide travel advice. They had a narrower remit than Ambassadors and had been prepared differently. Many had been given a choice between 'volunteering' to be Travel Champions or taking unpaid leave for the Games period (to minimise unnecessary travel and congestion). When these elements of payment and 'coercion' (Strickland, 2010) in the work of the Transport Champions are taken into account, questions are raised about the extent to which they were indeed 'volunteers' as understood in common parlance and academic literature (Wilson, 2012). Yet it seems that the GLA's 'Team London' section provided similar uniforms because, from their viewpoint, both Travel Champions and Ambassadors were ultimately from the same (local authority) stable. In this respect, public sector norms overrode their commitment to sensitive volunteer management and there was a blurring not only of the meaning of 'volunteering' but also of the boundaries between volunteering and working for remuneration (Hustinx and Meijs, 2011).

\section{A Public Policy Legacy?}

For at least the last three decades there have been a variety of governmental initiatives in the UK to encourage active citizenship, community involvement and volunteering (Davis Smith, 2001: Rochester, 2006) and these continue in the era of 'Big Society' (Cabinet Office, undated). Does the experience of the TLAP, then, suggest useful lessons for public policy implementation? Does TLAP suggest new models for involving volunteers in public service delivery and a legacy of 'London 2012'?

Monitoring of social media in the Games period and immediately afterwards suggests that those who volunteered to be London Ambassadors had very good experiences and were glad to have participated. Publicly expressed complaints about working conditions have been minimal at the time of writing. People posting messages to the London Ambassadors page on Facebook, for example, were overwhelmingly happy to have had the opportunity to do something positive for London and for visitors to London. The only negative note as far as volunteers themselves were concerned came at the end of the Olympic Games when fulsome public thanks and gifts were offered to Games Makers while the 8,000 Team London Ambassadors and the hundreds of volunteers who performed in the opening and closing ceremonies were not publicised by LOCOG officials, by the media or, indeed, by the Mayor of London under whose auspices the TLAP was implemented. The lack of immediate public recognition was seen, according to postings on Facebook, as a bad reflection on the Greater London Authority and on the Mayor of London.

All the same, the implementation of the Team London Ambassadors programme, seems to reflect successful experiences in the USA of governmental organisations involving volunteers (Brudney and Kellough, 2000; Rehnborg, 2005). It also seems to confirm the arguments of Haski-Leventhal et al 
(2010) that there is scope for public sector organisations to expand their role in recruiting, training and managing volunteers. If volunteers are enthused by a cause, they are not, it seems, put off by having to work within a public sector organisational framework or according to public sector norms; a point which seems to reflect the experience of the National Health Service and the criminal justice system in involving volunteers in the UK (Milligan and Fyfe, 2005). Indeed, where there is a need for recruitment and training of volunteers on a large scale, local government organisations may be especially well placed to provide the systems and organisational infrastructure needed. Ironically, the need for public sector organisations to expand their role in involving volunteers may increase as those same public sector organisations continue to reduce substantially their funding for voluntary sector infrastructure bodies (NAVCA, 2012).

Yet the experience of the TLAP during the Olympics period also suggests that policy makers and policy implementers should move cautiously into the world of directly recruiting, training and managing volunteers. Delegating management of volunteers to other volunteers was an essential feature of TLAP and a contributor to minimising the costs of the programme but is not appropriate for every kind of volunteer-delivered service (Hill and Stevens, 2011). Again, the scope for local authorities to exercise quality control over the service delivered by 'their' volunteers may be limited - a point which seems to have been well understood by the Team London officers of the GLA who planned and implemented the TLAP. But it is a point which might cause some concerns around public sector accountability in other kinds of projects where consistency of service quality is more important (for example, in projects where volunteers are providing care for vulnerable people).

A second note of caution for policy makers is illustrated by the publicly expressed resentment of Ambassadors at the end of the Games period when they felt they had not received the level of recognition given to Games Maker volunteers. It seems that the Team London officers had adopted some, but not all, of the accepted principles of good practice in volunteer management (Hager and Brudney, 2004; Machin and Paine, 2008). They failed to note fully the implications of earlier findings that volunteers have both altruistic and egotistic motivations (Steen, 2006). Pins, certificates, discounts, gifts, uniforms and 'freebies' appeal to some people and often the very experience of being a volunteer is its own reward. All the same, as postings to Facebook during and after the Games made clear, there is no substitute for a heartfelt public 'thank you' to a volunteer in recognition of work done.

It would be helpful for future research to investigate in more detail the organisational structures and principles which underpinned the Team London Ambassadors Programme in order to tease out the factors which underpinned its generally positive reception by volunteers and by the public. Initial indications are that a critical success factor was that the core Team London staff within the GLA were able to build on prior knowledge of volunteering and voluntary sector norms in developing the Ambassadors Programme and in making decisions about how it should be managed in the field. The Ambassadors Programme differed from earlier Team London work in that it involved direct recruitment and training of substantial numbers of volunteers, rather than simply providing a matching service between volunteers and volunteer-involving organisations. All the same, GLA staff were able to build on contacts with community organisations and knowledge of volunteer management norms acquired in the course of working in a specialist unit focused on volunteer engagement (2). Local authorities wishing to expand their role in volunteer involvement might be 
well advised to build up their practical expertise in the field of volunteering and citizenship in a similar way.

In short, TLAP experience suggest that there is scope in the UK for more public sector involvement in encouraging people to take on societal tasks as good citizens. However, the accumulated voluntary sector research about what motivates volunteers and best management practice should be seen as applying not only to the voluntary sector but equally to volunteers recruited, trained and managed by public sector organisations. The challenge for public sector organisations is to combine good volunteer management practices with attention to their own distinctive needs to ensure public accountability and quality control in service delivery.

\section{Endnotes}

(1) More limited volunteer Ambassador programmes were sponsored by local authorities in some other areas of the UK where Games-related activities occurred, including Weymouth and Coventry.

(2) Some factual details in this article were obtained by the author in the course of her own volunteering as a Team London Ambassador and in personal communications with Ambassador volunteer managers.

\section{References}

Alcock, P. (2010) Building the Big Society: A New Policy Environment for the Third Sector in England Voluntary Sector Review 1,3 379-390

Brudney, J. and Kellough, J.E. (2000) Volunteers in State Government: Involvement, Management and Benefits Nonprofit and Voluntary Sector Quarterly 29,1 111-130

Cabinet Office (undated) Big Society - Overview http://www.cabinetoffice.gov.uk/content/bigsociety-overview accessed August 2012

Clary, E.G.; Snyder, M.; and Ridge, R. (1992) Volunteers' Motivations: A Functional Strategy for the Recruitment, Placement and Retention of Volunteers Nonprofit Management and Leadership 2,4 333-350

Clark, J.; Kane, D.; Wilding, K.; and Bass, P. (2012) The UK Civil Society Almanac 2012 Lonond: National Council for Voluntary Organisations

Davis Smith, J. (2001) Volunteers: Making a Difference? in Harris, M. and Rochester, C. (eds) Voluntary Organisations and Social Policy in Britain Basingstoke: Palgrave Macmillan Farrell, J.M.; Johnston, M.E.; and Twynam, G.D. (1998) Volunteer Motivation, Satisfaction and Management at an Elite Sporting Competition Journal of Sport Management 12,4 288-300

Hager, M. and Brudney, J. (2004) Volunteer Management Practices and Retention of Volunteers Washington, D.C.: Urban Institute 
Haski-Leventhal, D., Meijs, L. and Hustinx, L. (2010) The Third Party Model: Enhancing Volunteering through Governments, Corporations and Educational Institutes Journal of Social Policy 39,1 139-158

Hill, M. and Stevens, D. (2011) Volunteers who Manage other Volunteers and the Professionalisation of Volunteer Management: Implications for Practice Voluntary Sector Review 2,1 107-114

Hustinx, L. and Meijs, L. (2011) Re-embedding Volunteering: in Search of a New Collective Ground Voluntary Sector Review 2,1 5-22

Lee, M. (2006) The Race for the 2012 Olympics: The Inside Story of How the Bid was Won London: Virgin Books

Liao-Troth, M. (2001) Attitude Differences between Paid Workers and Volunteers Nonprofit Management and Leadership 11,4 423-442

Machin, J. and Paine, Ellis A. (2008) Management Matters: A National Survey of Volunteer Management Capacity London: Institute for Volunteering Research

Milligan, C. and Fyfe, N. (2005) Preserving Space for Volunteers: Exploring the Links between Voluntary Welfare Organisations, Volunteering and Citizenship Urban Studies 42,3 417-433

Mayo, M.; Mendiwelso-Bendek, Z; and Packham, C. (2012) Learning to Take Part as Active Citizens: Emerging Lessons for Community Organising in Britain Voluntary Sector Review 3,2 179-195

NAVCA (2012) Funding Local Voluntary and Community Action Sheffield: NAVCA

Nichols, N. and Ojala, E. (2009) Understanding the Management of Sports Events Volunteers Through Psychological Contract Theory Voluntas 20,4 369-387

Nichols, G.; Taylor, P.; James, M.; Holmes, K.; King, L.; and Garett, R. (2005) Pressures on the UK Voluntary Sport Sector (2005) Voluntas 16,1 33-50

Office of Mayor of London (2012) Team London Ambassadors: Volunteer Manual London: Office of Mayor of London

Paine, Ellis A.; Ockenden, N.; and Stuart, J. (2010) Volunteers in Hybrid Organizations: A Marginalised Majority? In Billis, D. (ed) Hybrid Organizations in the Third Sector Basingstoke: Palgrave Macmillan

Rehnberg, S.J. (2005) Government Volunteerism in the New Millenium in Brudney, J. (ed) Emerging Areas of Volunteering Indianapolis: ARNOVA

Rochester, C. (2006) Making Sense of Volunteering: A Literature Review London: Commission on the Future of Volunteering

Shaw, S. (2009) "It was all 'Smile for Dunedin!'”: Event Volunteer Experiences at the 2006 New Zealand Masters Games Sport Management Review 12, 1 26-33

South, J. and Kinsella, K. (2011) Citizens Bridging the Gap? Interpretations of Volunteering Roles in Two Public Health Projects Voluntary Sector Review 2,3 297-316 
Steen, T. (2006) Public Sector Motivation: Is there Something to Learn from the Study of Volunteerism? Public Policy and Administration 21,1 49-62

Strickland, A. (2010) Recent Developments in Volunteering and Citizenship Voluntary Sector Review $1,2253-258$

Team London Ambassadors website (undated) Your London Needs You

http://www.londonambassadors.org.uk/ (accessed August 2012)

Team London website (undated) What is Team London? http://www.london.gov.uk/teamlondon/ (accessed August 2012)

Wilson, J. (2012) Volunteerism Research: A Review Essay Nonprofit and Voluntary Sector Quarterly 41,2 176-212 